\title{
Where should police forces target their residential burglary reduction efforts? Using official victimisation data to predict burglary incidences at the neighbourhood level
}

\author{
James Hunter ${ }^{1^{*}} \mathbb{0}$, Bethany Ward ${ }^{1}$, Andromachi Tseloni ${ }^{1}$ and Ken Pease ${ }^{2}$
}

\begin{abstract}
Expected crime rates that enable police forces to contrast recorded and anticipated spatial patterns of crime victimisation offer a valuable tool in evaluating the under-reporting of crime and inform/guide crime reduction initiatives. Prior to this study, police forces had no access to expected burglary maps at the neighbourhood level covering all parts of England and Wales. Drawing on analysis of the Crime Survey for England and Wales and employing a population terrain modelling approach, this paper utilises household and area characteristics to predict the mean residential burglary incidences per 1000 population across all neighbourhoods in England and Wales. The analysis identifies distinct differences in recorded and expected neighbourhood burglary incidences at the Output Area level, providing a catalyst for stimulating further reflection by police officers and crime analysts.
\end{abstract}

Keywords: Burglary, Crime incidence, Population terrain modelling, Crime reduction

\section{Introduction}

The spatial concentration of crime is a given in both academic criminology (Weisburd, 2015) and policing lore (McLaughlin et al., 2007). Residential burglary is no exception. While burglary hot spots are somewhat 'slippery' in space (Johnson \& Bowers, 2004) and 'bursty' over time (Johnson et al., 2012), much of the variation in neighbourhood and street segment burglary rates remains attributable to relatively enduring household and area characteristics (Andresen et al., 2017; Bernasco \& Block, 2010; Bowers et al., 2005; Johnson et al., 2009; Morenoff et al., 2001; Tseloni, 2006; Vandeviver \& Steenbeek, 2019). Crime concentrations offer police forces the opportunity to target interventions within crime hotspot areas in order to reduce crime (Sherman et al., 1989).

\footnotetext{
*Correspondence: james.hunter@ntu.ac.uk

${ }^{1}$ Nottingham Trent University, Nottingham, UK

Full list of author information is available at the end of the article
}

Unsurprisingly, hotspot policing has become an established approach to responding to crime in the wake of drives to introduce intelligence-led policing (Andresen \& Weisburd, 2018; Ratcliffe, 2004).

While badged as 'intelligence-led', simply designating an area as a hot spot based on police recorded crime neglects much of what we know about burglary dynamics. For instance, the spatial diffusion of crime reduction benefits beyond those neighbourhoods subject to hot spot policing far outweighs any reciprocal crime displacement that may occur (Braga et al., 2019). A range of known crime-contingent dynamics is also neglected in basic hot spot policing. These include repeat victimisation, near-repeat victimisation, and anticipatory diffusion of benefits (Ignatans \& Pease, 2018). The crime hotspot map placed before police officers and crime analysts represents a crime environment that is a product of many interwoven factors. These can include the characteristics, movement and behaviour of resident and ambient

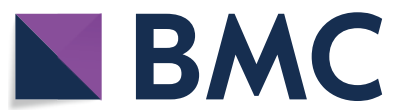

(c) The Author(s) 2021. This article is licensed under a Creative Commons Attribution 4.0 International License, which permits use, sharing, adaptation, distribution and reproduction in any medium or format, as long as you give appropriate credit to the original author(s) and the source, provide a link to the Creative Commons licence, and indicate if changes were made. The images or other third party material in this article are included in the article's Creative Commons licence, unless indicated otherwise in a credit line to the material. If material is not included in the article's Creative Commons licence and your intended use is not permitted by statutory regulation or exceeds the permitted use, you will need to obtain permission directly from the copyright holder. To view a copy of this licence, visit http://creativeco mmons.org/licenses/by/4.0/. The Creative Commons Public Domain Dedication waiver (http://creativecommons.org/publicdomain/ zero/1.0/) applies to the data made available in this article, unless otherwise stated in a credit line to the data. 
populations (Summers \& Johnson, 2017); the location and motivation of offenders (Townsley \& Sidebottom, 2010); the presence of crime attractors and generators (Bernasco \& Block, 2010); levels of social cohesion (Morenoff et al., 2001); as well as policing strategies and crime reduction initiatives (Weisburd et al., 2014). Disentangling the impact of each of these crime catalysts in order to inform resource allocation and the targeting of initiatives in the absence of hard evidence remains a problem for police analysts. It cannot be achieved by merely overlaying crime hotspot data onto neighbourhood-level deprivation, population characteristics, or points of interest maps. Furthermore, there is the danger that such crime maps are taken as reflecting a 'given' crime environment and that future risk of victimisation can be falsely inferred from the simple presence of crime hot spots within specific neighbourhoods or streets.

Aside from the methodological issues surrounding the accurate identification of hot spots (Ignatans \& Pease, 2018), we suggest that reactive or proactive police resource allocation models predicated simply upon hotspot analysis miss a crucial aspect. The operational and analytical focus upon actual crime events (within often short time frames) removes the potential for decisionmaking/resource allocation that is informed by an alternative virtual crime landscape component. Whilst these provide a useful means for testing propositions within criminological theory (Birks et al., 2012), they also offer up a mechanism for challenging preconceptions concerning the 'where and when' of crime hotspot locations. Given the importance of the prevailing underlying characteristics of individuals, households and neighbourhoods in shaping burglary victimisation (Tseloni, 2006; Tseloni \& Pease, 2014; Tseloni et al., 2004), the focus of neighbourhood policing should equally consider where burglary hot spots are to be expected and the extent to which they diverge from police recorded burglary levels. Those responsible for operational decision-making are then enabled to ask both (a) why the expected levels of burglaries have not occurred in some areas and (b) why the actual level of burglary in other places exceeds the expected level? According to the Crime Survey for England and Wales (CSEW), on average only sixty-five per cent of residential burglaries in a dwelling were reported to the police between April 2001 and March 2020 (Office for National Statistics [ONS], 2020a). Factors such as personal characteristics and deprivation that shape nonreporting are also likely to be spatially concentrated (Goudriaan et al., 2006). Virtual residential burglary landscapes therefore provide a means of identifying the extent and spatial location of under-reported incidents.

Conversely, where expected burglary rates are lower than police recorded incidents, this enables identifying areas that appear to be 'beating the odds' based on neighbourhood characteristics informed expectations. In both instances, virtual crime landscapes identify areas for attention based on deviation of police recorded crime from the expected, thus providing reasonable targets for neighbourhood policing in areas other than hot spots. Having neighbourhood-specific notional base rates also informs the evaluation of crime reduction advice and other targeted crime reduction interventions, the presence of greater levels of effective security, or police patrols-and answers the critical question: 'What are the policy lessons arising from these outcomes?'.

To pursue this suggested approach, police forces need data on expected burglary levels in their jurisdictional neighbourhoods. Existing methodological approaches to predictive crime incidence mapping can be divided into event-based, area-based, and behavioural (agent-based) approaches. Event-based methodologies embrace the concept of near-repeat victimisation and the spatiallyconstrained 'contagiousness' of individual crime events to identify nearby households and properties at immediate heightened risk following a crime (e.g., Bowers et al., 2004) - and then aggregate these to develop area-level risk maps. In contrast, area-based approaches, such as risk terrain modelling (Kennedy et al., 2010), seek to capture the ecological context of crime hot spots and identify the collective risk posed by the physical criminogenic attributes and features of specific locations in relation to particular crime types (e.g., Moreto et al., 2014). Finally, agent-based modelling generates expected crime incidence levels arising from the interaction of independent agents (offenders) operating upon defined decision-making parameters (e.g., the need to acquire drugs, willingness to travel further to offend) moving through specific physical environments (e.g., streetscapes) containing specific criminogenic features (e.g., alcohol outlets) (e.g., Malleson et al., 2009). Whilst all three approaches have potential applications across larger spatial scales, the microsimulation focus on individuals and streets (and the computational logistics of extending the analysis to larger geographical areas) has resulted to date in expected neighbourhood-level burglary rates only within specific cities in England (e.g., Malleson et al., 2010).

This paper provides an overview of the predictive neighbourhood level burglary maps developed by the authors that the Home Office commissioned in order to address the absence of an evidence-base that covered all neighbourhoods across all police force areas in England and Wales. These maps form part of the Crime Prevention Toolkit made available in 2020 and 2021 to Police and Crime Commissioners to aid the development of their funding bids to the ongoing Home Office Safer Streets Fund (Home Office, et al., 2021). Utilising 
an area-based approach to predictive crime mapping, a form of population terrain modelling has been developed that yields expected burglary levels occurring within all neighbourhoods at the Output Area level across England and Wales based upon the relative presence of virtual population groups with specific individual, household and area deprivation characteristics. Output Areas (the defined neighbourhoods within this study) are the lowest spatial geographical scale employed within official statistics in the UK. There are 175,434 Output Areas in England and Wales, eighty per cent of which contain between 110 and 139 households (ONS, 2016).

The paper commences with a discussion of the analysis of CSEW data employed to identify the risk and protective factors that shape the mean number of burglaries experienced by different households within different contexts. This discussion is followed by an overview of the methodology and official datasets deployed to transform the findings from this empirical analysis into online interactive predictive neighbourhood-level burglary maps. This component includes some reflections on data limitations and where data collection and availability require further development. The paper concludes with a discussion of how these maps can be utilised to target burglary reduction advice in combination with other measures.

\section{Identifying household and area factors that shape increased burglary victimisation in England and Wales}

The opportunity structures that shape burglary victimisation risk are influenced by a wide range of factors, including the time and day of the week (Andresen \& Malleson, 2015), property type (Bowers et al., 2005), presence, and type of, security (Tseloni et al., 2017), the nature of the built environment and visual clues afforded to offenders (Armitage, 2018), street networks and spatial interactions (Chiaradia et al., 2009), offenders' journey to crime (Vandeviver et al., 2015) the behavioural decisions of offenders (Malleson et al., 2009), as well as police responses to reducing burglary, such as hotspot policing (Braga et al., 2019).

Despite lack of concurrent evidence on the above factors to date, population-based crime survey data (such as the CSEW), measure directly (i.e., property type and presence of security), or implicitly (i.e., proximity to offenders), a wide range of crime opportunity structures and burglars' modus operandi (Tseloni et al., 2018). Drawing on crime surveys we can therefore identify types of households burgled (and how often), and the sociodemographic profile of the areas they reside in (Tseloni, 2006), in order to estimate the mean number of burglaries likely to be experienced by virtual population groups "so that [neighbourhood] burglary rates can be calculated"
(Curtin et al., $2001[\mathrm{v}]$ ). However, prior to this study, information on the respective contribution of household and area risk and protective factors to expected aggregate burglary rates has not been transformed into a policy tool that can inform police force interventions at a neighbourhood level.

The household and area factors shaping the mean number of burglaries experienced in a year are taken from the CSEW, which is a nationwide survey administered by the Office for National Statistics (ONS), and at the time of writing, provides the only source of national (non-lethal) crime statistics. Regarded as a "gold-standard survey of its kind" (Flatley, 2014, p. 199) due to the rigorous survey methodology and consistently high response rates (maintained at $75 \%$ ), the CSEW uses a stratified multi-stage cross-section sample design with over-representation of low population density areas and continuous annual rotation. The CSEW sample of about 35,000 respondents (one per sampled household) per annum represents the population aged 16 years old or older living in households in England and Wales (ONS, 2018). The survey questionnaire collects information about crime and related experiences in the 12 months prior to the interview, perceptions, factual information about the respondents, their households and areas of residence, and diverse crime, crime prevention and criminal justice-related issues. The CSEW collects detailed information on respondents' and their households' crime victimisation experiences in the Victimisation Module (VM) which, in addition to detailed accounts of each crime event and its consequences, ensures back-office checks and correct crime classification. The VM is administered to those providing positive answers to an array of crime screener questions. The maximum number of VMs per respondent is six; prioritised in order of crime seriousness to capture rare events. Repeat burglary victims can fill up to $6 \mathrm{VMs}$ (one per burglary experienced) or less if they also experienced violence, the only more serious offence than burglary, in the previous year. In addition, any series crimes-repeat incidents where "the same thing was done under the same circumstances and probably by the same people" (Hales, 1993: 12)-are capped at 5 with one VM per series incident, which however does not affect burglary estimates due to the nature of this crime (ONS, 2019a).

This study utilised raw data from four sweeps of the CSEW, 2014/15-2017/18 (UKDS SNs 7889, 8140, 8321, 8464), the latest available in the public domain at the time of analysis, with a merged sample (after data cleaning) of 138,155 households $(127,357$ in England and 10,799 in Wales) to model the expected number of burglaries per household over household and area of residence characteristics. Their selection was theoretically driven based 
upon previous empirical research findings but, as will be explained in the next paragraph, deliberately restricted to those variables with open access data on OAs household and dwelling composition. The variable of primary interest is residential burglary ${ }^{1}$ count per household $\left(x_{i}=0,1\right.$, $2, \ldots, 12$; mean $=0.027$; standard deviation $=0.216$; skewness $=15.601)$ in the 12 months prior to the interview, covering burglary in a dwelling, including attempts, and in other buildings within the property boundary, such as outhouses and garages (CSEW offence codes: 51-53, 57 , and 58). ${ }^{2}$ The residential burglary count was based on VM's offence classification and modelled via the negative binomial regression model, which accounts for crime overdispersion (Cameron \& Trivedi, 1986; Osborn \& Tseloni, 1998). Indeed, the vast majority of English and Welsh households $(97.9 \%)$ were not burgled, $1.8 \%$ were burgled once, $0.2 \%$ twice and the remaining three to twelve times, giving an average of 1.29 burglaries per targeted household.

Although the CSEW includes rich information reflecting burglary opportunities, we explicitly included in the model only those factors where the relevant OA level data is open access (https://www.nomisweb.co.uk). These are (with reference characteristics in italics): sex (male or female), age (16-99, quadratic) and ethnicity (White, Black, Asian sub-continent or Mixed, Chinese, Other) of the Household Reference Person (HRP); household composition (single adult at least 65 years old or under 65 , two, or three or more adult household, with children, and lone parent household); tenure (social tenant, private renting, or owner occupier); accommodation type (detached, semi-detached, terraced or flat, maisonette or other); number of cars at the household's disposal (zero, one, two, three or more); respondent with long term illness or disability (non-limiting, limiting or no long term illness or disability); household moved in the previous twelve months; area type (rural, urban, or inner city); the nine English regions (with reference region South East excluding Greater London); and few non-correlated

\footnotetext{
${ }^{1}$ Residential burglary replaced domestic burglary in the policy agenda in 2013 but the CSEW offence codes allow over time comparisons (https://www.gov. uk/government/publications/counting-rules-for-recorded-crime). "Residential burglary includes all buildings or parts of buildings that are within the boundary of, or form a part of, a dwelling and includes the dwelling itself, vacant dwellings, sheds, garages, outhouses, summer houses and any other structure that meets the definition of a building. It also includes other premises used for residential purposes such as houseboats, residential care homes and hostels." (https://assets.publishing.service.gov.uk/government/uploads/system/uploa ds/attachment_data/file/791088/count-burglary-apr-2019.pdf).

2 Attempted burglary in outbuildings (offence code 50) has been excluded because it is hard to prove and may often be recorded as criminal damage. Across the four years 221 individuals reported attempted burglary in outbuildings ( $0.16 \%$ of the sample).
}

Indices of Multiple Deprivation (IMD): income and barriers to housing domains for England and income, barriers to services and physical environment domains for Wales. ${ }^{3}$ Except for HRP age, and IMD, all other household and area characteristics variables are categorical and entered the statistical model as a set of dummy variables contrasting with a reference value-the one given in italics in the above lists-per variable; and all put together describe a synthetic reference household. The factors ${ }^{4}$ significantly affecting the mean number of burglaries a household is expected to experience with their contribution relative to the respective reference characteristic are given in Fig. 1a and $\mathrm{b}$.

The significant factors that enhance the number of burglaries relative to the base household in England include individual characteristics (HRP Asian), household formation (single adult [both under and over 65], lone parent, housing tenure (movers, social renting), car-ownership (both no car and three or more cars), health (both nonlimiting and limiting illness) as well as area-based factors (urban). Households whose head is either female or Black, who live in semi-detached houses or flats, who own a single car, in inner-city areas, and neighbourhoods with less income deprivation enjoy less expected burglaries compared to the base household. In Wales, there are fewer risk and protective characteristics: being a social renter, moved in the previous year, owning three or more cars, suffering from either non-limiting or limiting illness, and in areas with poor access to services results in more expected burglaries-whilst only living in a semidetached property, in an urban area, and in a neighbourhood with less income deprivation offers any degree of relative protection. The above are consistent with theory and previous national and cross-national evidence on population group burglary risk across various survey iterations, sampling methodology and statistical modelling technique since the 1980s (ONS, 2019b; Osborn \& Tseloni, 1998). Although not originally mentioned within lifestyle/routine activities theory, from an opportunity crime theory perspective, disability combines several elements of suitable target: perceived victim's physical, mental and emotional vulnerability, potential offender impunity (especially regarding victims with learning or difficulty in communication disabilities) and recently more goods to steal in the form of gadgets to assist everyday life and social interaction. The model also incorporates two interactions (single adult household by age

\footnotetext{
${ }^{3}$ Welsh IMD domains and reference year differ to the English ones. To account for this and the different population profile we estimated separate statistical models and a preliminary one across both England and Wales.

${ }^{4}$ HRP Age was also significantly related to (the exponential of) burglaries via inverse U slope for England and linear negative slope for Wales.
} 


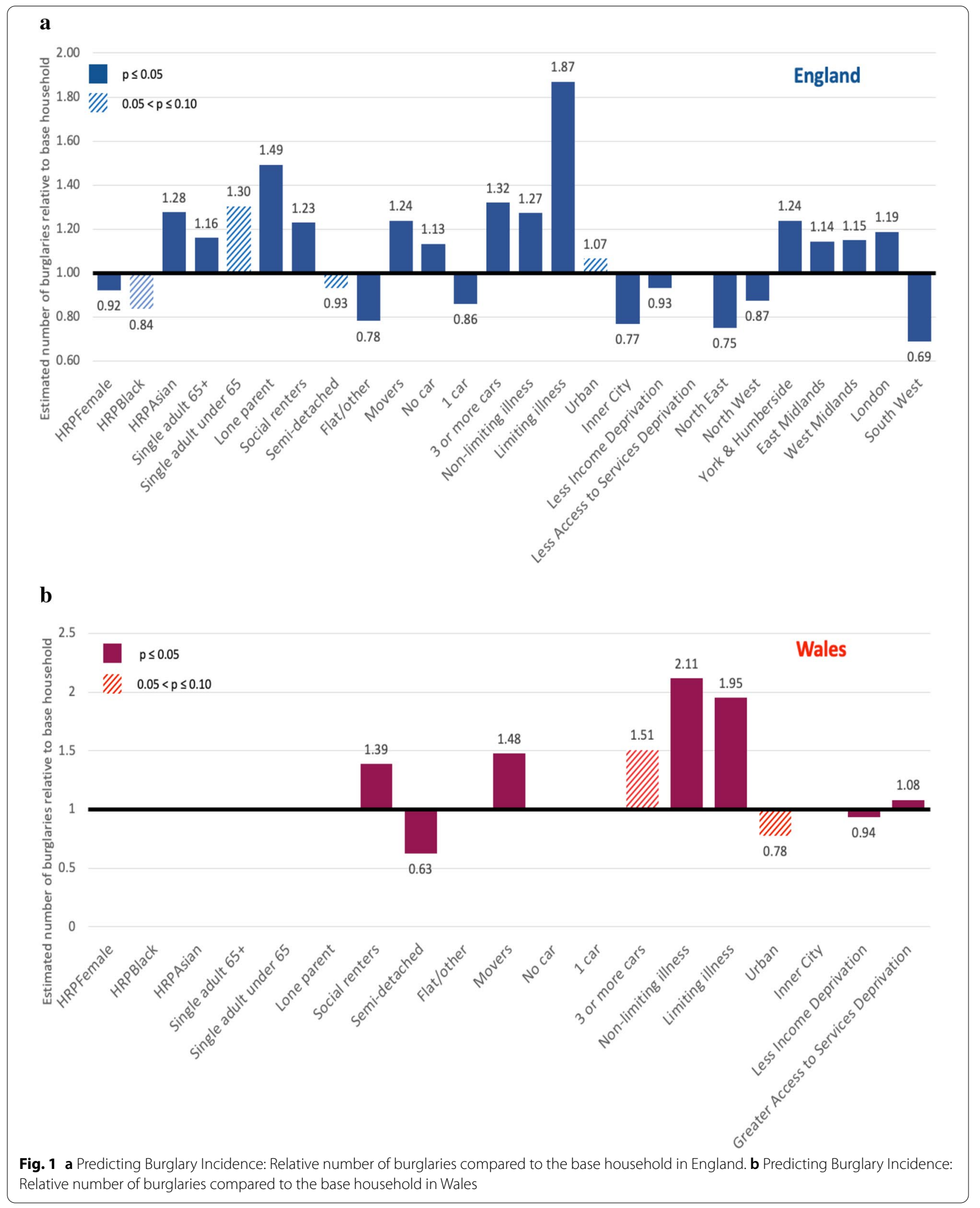


group and lone parent) available in OA profiles whilst further cross-cluster interactions did not add to the individual effects, despite previous research evidence (Tseloni, 2006). Therefore, we are confident that the only source of potential model misspecification is the omission by construction of significant factors that are not publicly available, notably household income group and security devices (Tseloni et al., 2017).

Having identified the individual, household and area characteristics that significantly shape mean household burglary incidences, the next challenge was to convert these into expected burglary rates maps that cover all neighbourhoods at the Output Area level across England and Wales.

\section{Developing expected burglary maps at the neighbourhood-level}

The empirical analysis above identified the mean number of burglaries in a twelve-month period that a household is likely to experience based on each independent explanatory factor and their interactions within the statistical model. By combining the respective mean burglary rates for a combination of these characteristics, it is possible to calculate the number of expected mean burglary incidences for a household possessing a combination of these characteristics, e.g., male, ethnic minority, lone parent household, living in a social rented terraced house, and in a deprived area. In order to construct the virtual population groups for each neighbourhood, we therefore:

(a) identified all of the potential different household types that exhibit different combinations of the identified risk and protective factors (e.g., white, owner-occupier, living in detached property in a less deprived locality);

(b) calculated the overall mean rate of burglary incidences for each of these household types based upon their specific risk and protective factor combination of characteristics (i.e., mean rate White + mean rate Owner + mean rate Detached + mean rate low deprivation decile);

(c) identified the relative presence of each of these household types within each neighbourhood;

(d) weighted these household type proportions by the relevant expected mean number of burglaries; and

(e) summed together with the weighted scores for each household type in order to derive an overall expected mean number of burglaries for all households living within the neighbourhood.

Data availability resulted in specific revisions to our original methodological approach. Due to disclosure concerns, the Census 2011 data at the small area level required to identify every virtual household combination is only available through a secure license. The time frame for generating the expected neighbourhood level maps on behalf of the Home Office necessitated the utilisation of open-access data. Household types were therefore constructed based on gender, household composition and age, tenure, type of accommodation, health and deprivation levels. Even in this instance, in order to achieve certain combinations, it was necessary to apply, for example, the respective health status ratios at the Output Area level in respect of different virtual households, and the distribution of these households across accommodation types, in order to derive the required combination estimate.

Police forces were provided access to the neighbourhood level expected burglary maps via the Police Knowledge Hub hosted by South Yorkshire Police. Regional maps for England, and a separate version for Wales, were created that enabled the user to focus upon a specific police force, local authority, or community safety partnership area. Following discussions with the Home Office, and to enhance the policy tool's decision-making value, a series of previously non-existent police force area maps were generated. These enabled analyses at the Output Area level of (a) police recorded burglaries per 1000 population; (b) level of police-recorded burglaries relative to police force area burglary average; and (c) burglaries as a share of all acquisitive crime. In order to enable police forces to focus upon the respective burglary indicators within similar localities, the online maps also incorporated the 2011 Output Area Classification. ${ }^{5}$ This uses hierarchical cluster analysis to classify all neighbourhoods across the United Kingdom into twenty-four different types (e.g., Ageing Rural Industry Workers, Hard-Pressed Ethnic Mix, Social Renting New Arrivals).

To illustrate the practical application of the expected burglary maps, Fig. 2 presents the difference between the expected residential burglary rate per 1000 population and the police recorded burglary rate per 1000 population in 2019 at the OA level in Manchester, a former location for trade and industry, but now a business, heritage and education centre Core City in the north-west of England. The open-source police recorded burglary data obtained from Police.UK includes both residential and non-residential burglary data. ${ }^{6}$ Non-residential burglaries (on average $32.5 \%$ with a minimum of $21.6 \%$ and a maximum of $54.5 \%$ in England and Wales, ONS, 2020b) will mirror the spatial concentration of business

\footnotetext{
5 https:/www.ons.gov.uk/methodology/geography/geographicalproducts/ areaclassifications/2011areaclassifications.

6 The authors did not have access to the original data from each police force that would have enabled the identification of only residential burglaries.
} 


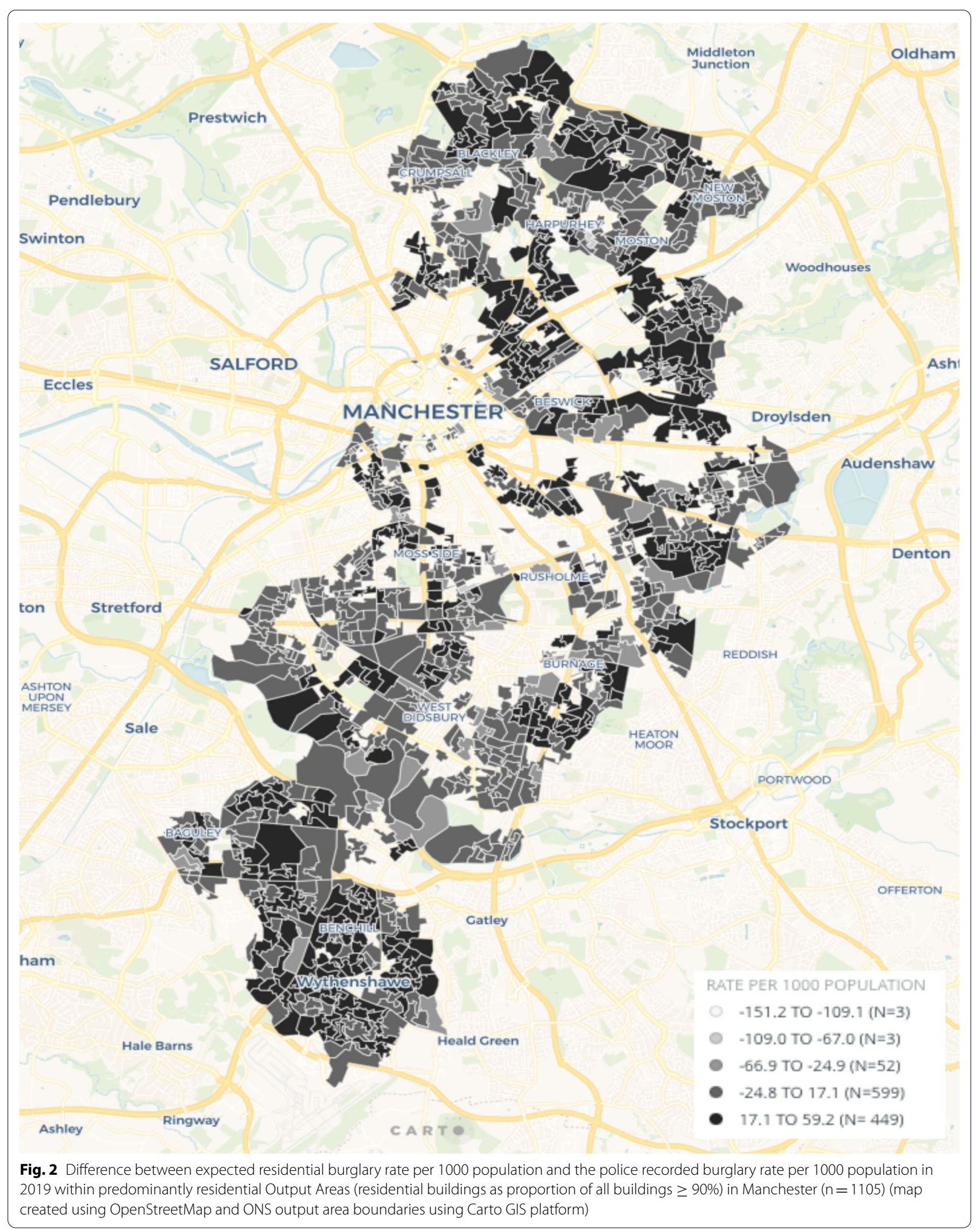


and retail properties within city and town centres. Whilst this has a limited impact on comparisons in residential areas (the vast majority of neighbourhoods within cities and towns), caution should be exercised in comparing police recorded and expected mean burglary incidences within business and retail dominated zones. To overcome the limitation of the presence of non-residential burglary data, the GEOMNI UK Buildings Database was used to identify the percentage of designated residential buildings in each OA in order to identify predominantly residential neighbourhoods. Figure 2 therefore only presents data for those OAs where residential buildings constitute at least ninety per cent of all buildings-and hence where the vast majority of police-recorded burglaries relate to residential properties.

The difference between the expected residential burglary and the police recorded burglary rate across the 1105 predominantly residential neighbourhoods ranges from - 151.2 to 59.2 per 1000 population. The majority of neighbourhoods (71.4 per cent) have an expected burglary rate that exceeds the police recorded burglary rate, with 51.5 per cent having an expected burglary rate of 10 incidences per 1000 population greater than the policerecorded burglary level. The greater differences between expected residential and police recorded burglaries presented in Fig. 2 are spatially concentrated within certain neighbourhoods in the northern, central and southern parts of the city. This is because the households possessing the relevant risk and protective characteristics are also geographically located across Manchester.

For the neighbourhood policing teams and crime analysts operating within Greater Manchester, the predominance of neighbourhoods with greater expected residential burglary levels offers up a number of scenarios to consider. First, this outcome might point to a high level of under-reporting of residential burglaries to the police across a large number of neighbourhoods within the city. In a recent analysis of factors shaping spatial variations in the under-reporting of all crimes at the Middle Super Output Area level across England and Wales, Buil-Gil et al. (2021) identified that neighbourhoods with high/low differences from average income levels, fewer residents with higher or intermediate occupations, lower mean house prices, higher proportions of non-Asian ethnic minorities, and people with low qualificationsare significantly related to the under-reporting of crime. Consideration by police officers and crime analysts of a range of official datasets such as the 2011 Census would quickly reveal an over-representation of all of these characteristics across many neighbourhoods in Manchester. Further detailed investigation is clearly required, and it is unlikely that the impact of these factors on non-reporting of crimes is consistent across all offence types. The higher expected residential burglary rates across the majority of neighbourhoods in Fig. 2, however, illustrates the potential for predictive neighbourhood-level crime maps to initiate, or further develop, investigation of the spatial concentration of crime under-reporting.

The second scenario to emerge from the evidence presented in Fig. 2 is that negative differences between expected and police recorded incidents point to the success of crime reduction initiatives, the target hardening of properties with effective security combinations, and policing activity in thwarting potential residential burglaries within specific neighbourhoods in Manchester. Thus, it is immediately apparent that this comparison between police recorded and expected burglary levels offers up to Greater Manchester Police a series of localities that merit further exploration to determine why the police recorded 'real world' and 'virtual' burglary outcomes are so different.

\section{Discussion and conclusion}

This paper has presented a methodology for analysing CSEW data in order to develop expected mean burglary incidences for neighbourhoods across England and Wales using open-source official data sets. Whilst the focus here has been on burglary, the approach developed by the authors can easily be (a) used to develop virtual crime landscapes in relation to other offence types and anti-social behaviour incidents, and (b) extended to cities and jurisdictions outside of England and Wales providing the relevant victimisation survey and small area data is available.

There are a number of limitations to the analysis presented within this paper. First, the accuracy of the expected number of burglaries requires further refinement by utilising the actual household characteristics combination data at the OA level (as opposed to the household typologies constructed using the open-access Census 2011 data). Second, due to data limitations, potential significant factors in shaping burglary victimisation, such as income or the presence of house security devices, do not feature within our statistical model. Third, hierarchical modelling (which would have accounted for area conditioning (random) individual effects) was not employed due to data confidentiality. Finally, in comparing police-recorded burglaries with the burglary estimates presented here, it should be noted that the former contains both residential and non-residential burglaries.

What should be next for research and implementation of the approach developed here? Firstly, a possible step would be to identify neighbourhoods that experienced much lower police-recorded residential burglary rates than the CSEW-model estimates suggest and seek to determine their identifying characteristics relative 
to neighbourhoods with similarities between the two source levels. Comparison with neighbourhoods suffering higher than expected rates of residential burglary should await the results of the less reputationally damaging comparison. Secondly, burglary is not the only crime of interest, so developing the approach with other offence types should proceed in parallel with the first suggestion. Thirdly, a discussion should be held as to how to implement the predictive approach developed here into mechanisms concerning police resource allocation and the targeting of burglary reduction initiatives. It has the advantage of representing areas as high or low relative to expectation rather than good or bad, thus bypassing such stigmatisation of areas. It also provides an incentive to focus upon less-challenged crime areas that may have previously lacked attention. Now, the incentive to reduce crime in 'nice' areas depends wholly on police officer motivation. By expressing goals in terms of change towards lower-than-expected crime, a new motive is introduced for such areas. Fourth, and perhaps fundamental, though not a defect of the proposed approach, taking the expected level of burglary (or any crime) as a starting point, there is no particular incentive to improve area planning and the housing stock in crime reductive ways. In short, the approach here does not reduce the need for crime reductive design and construction; indeed, it may contribute by identifying design characteristics of neighbourhoods with lower-than-expected police recorded rates of burglary.

From a policy perspective, the expected burglary neighbourhood-level online maps provide crime reduction analysts and neighbourhood policing teams with an additional evidence base to underpin the targeting of crime reduction initiatives and advice within specific localities. Implementation issues are acknowledged to be complex but not insuperable. Offering security help based on household or neighbourhood attributes that are perhaps seen as shaming (e.g., lone parent or social renting) will invite stigma if the selection criterion becomes known. Then there is the question of the police's right to have the information feeding the identification of those at risk in the first place, and whether unsolicited proactive policing will incite fear of crime within the targeted virtual community. Any selection which excludes neighbours from benefitting from targeted crime reduction advice may invite accusations of unfairness, in addition to neglecting the literature on near repeats. There are potential tactical work-rounds, such as targeting an area with an uprated security package for those deemed most vulnerable (or scheduling them for priority attention). This approach could piggyback on a repeat victimisation project with the size of protective cocoons dependent upon the population.

The approach presented in this paper demonstrates the potential for generating expected neighbourhoodlevel incidence data and maps using victimisation survey data as opposed to police recorded burglary incidences. It also provides police forces and crime analysts with a means of disentangling the individual, household and area drivers of burglary levels from those relating to the built environment, offender location and movement, presence of household security, the allocation of police resources, and the targeting of preexisting crime reduction initiatives. In order to generate a holistic residential neighbourhood level burglary map, the presence of all of these catalysts is required. Some of this can be achieved using currently available open data sources. However, the inclusion of other aspects pertaining to operational policing demands access to data only in possession of individual police forces across England and Wales. Furthermore, there is currently no data on the presence of household security (either individually or in combination) at either the household or neighbourhood-level-and this remains a central barrier to the effective targeting of crime reduction initiatives designed to reduce residential burglary incidences.

\section{Acknowledgements \\ This work was initiated as a result of a previous ESRC SDAI Phase 1-funded project (ES/K003771/1). We are grateful to NTU Centrally Funded PhD Student- ship to the second author, as well as Billy Gazard, Office for National Statistics, and Joe Marshall, Home Office, for insightful discussions and initiating this study. Data citations: Office for National Statistics, ONS (2016-2019), Crime Survey for England and Wales, 2014-2015, 2015-2016, 2016-2017, 2017-2018, [data collection], UK Data Service, Accessed 1st December 2019. Respective SN: $7889,8140,8321,8464$}

\section{Authors' contributions}

AT and BW undertook the statistical modelling of the CSEW residential burglary data. JH undertook the statistical modelling and mapping relating to the development of the neighbourhood level predicted burglary maps. All authors contributed to the writing of different components of the manuscript. All authors read and approved the final manuscript.

Funding

This work was initiated as a result of a previous ESRC SDAI Phase 1-funded project (ES/K003771/1).

Availability of data and materials

Not applicable.

\section{Declarations}

Competing interests

The authors declare that they have no competing interests.

\section{Author details}

${ }^{1}$ Nottingham Trent University, Nottingham, UK. ${ }^{2}$ University of Derby, Derby, UK 
Received: 30 November 2020 Accepted: 24 April 2021 Published online: 05 June 2021

\section{References}

Andresen, M., Linning, S., \& Malleson, N. (2017). Crime at places and spatial concentrations: Exploring the spatial stability of property crime in Vancouver BC. Journal of Quantitative Criminology, 33, 255-275.

Andresen, M., \& Malleson, N. (2015). Intra-week spatial-temporal patterns of crime. Crime Science, 4(12), 1-11.

Andresen, M., \&Weisburd, D. (2018). Place-based policing: new directions, new challenges. Policing: An International Journal, 41(3), 310-313.

Armitage, R. (2018). Burglars' take on crime prevention through environmental design (CPTED): Reconsidering the relevance from an offender perspective. Security Journal, 31, 285-304.

Bernasco, W., \& Block, R. (2010). Robberies in Chicago: A block-level analysis of the influence of crime generators, crime attractors, and offender anchor points. Journal of Research in Crime and Delinquency, 48(1), 33-57.

Birks, D., Townsley, M., \& Stewart, A. (2012). Generative explanations of crime: Using simulation to test criminological theory. Criminology, 50(1), 221-254.

Bowers, K., Johnson, S., \& Pease, K. (2004). Prospective hotspotting: The future of crime mapping? British Journal of Criminology, 44, 641-658.

Bowers, K., Johnson, S., \& Pease, K. (2005). Victimisation and re-victimisation risk, housing type, and area: A study of interactions. Crime Prevention and Community Safety, 7, 7-17

Braga, A., Turchan, B., Papachristos, A., \& Hureau, D. (2019). Hot spots policing of small geographic areas effect on crime. Campbell Collaboration Systematic Reviews.

Buil-Gil, D., Medina, J., \& Shlomo, N. (2021). Measuring the dark figure of crime in geographic areas: Small area estimation from the Crime Survey in England and Wales. British Journal of Criminology, 61(2), 364-388.

Cameron, C., \& Trivedi, P. (1986). Econometric models based on count data: comparisons and application of some estimators and tests. Journal of Applied Econometrics, 1, 29-53.

Chiaradia, A., Hillier, B., \& Schwander, C. (2009). Spatial economics of crime: spatial design factors and total social cost of crime against individuals and property in London. Stockholm: Proceedings of the $7^{\text {th }}$ International Space Syntax Symposium. https://discovery.ucl.ac.uk/id/eprint/18605/1/ 18605.pdf. Accessed 10 October 2020

Curtin, L., Tilley, N., Owen, M., \& Pease K. (2001). Developing Crime Reduction Plans: Some Examples from the Reducing Burglary Initiative. Policing and Reducing Crime Unit. Crime Reduction Research Series Paper 7. London: Home Office.

Flatley, J. (2014). British crime survey. In G. Bruinsma \& D. Weisburd (Eds.), Encyclopaedia of criminology and criminal justice (ECCJ) (pp. 194-203). Springer-Verlag.

Goudriaan, H., Wittebrood, K., \& Nieuwberta, P. (2006). Neighbourhood characteristics and reporting crime: Effects of social cohesion, confidence in police effectiveness and socio-economic disadvantage. British Journal of Criminology, 46(4), 719-742.

Hales, J. (1993). 1992 British Crime Survey (England and Wales) Technical Report. Social and Community Planning Research.

Home Office, PCPI, SBD \& College of Policing (2021) "Safer Streets Fund - Crime Prevention Toolkit" January 2020. https://whatworks.college.police.uk/ Research/Documents/Safer_Streets_toolkit.pdf. Accessed 26 May 2021.

Ignatans, D., \& Pease, K. (2018). Crime concentrations: Hot dots, hotspots and hot flushes. In G. Bruinsma \& S. Johnson (Eds.), The Oxford handbook of environmental criminology (pp. 664-690). Oxford University Press.

Johnson, S., \& Bowers, K. (2004). The stability of space-time clusters of burglary. British Journal of Criminology, 44(1), 55-65.

Johnson, S., Bowers, K., Birks, D., \& Pease, K. (2009). Predictive mapping of crime by ProMap: Accuracy, units of analysis, and the environmental backcloth. In D. Weisburd, W. Bernasco, \& G. Bruinsma (Eds.), Putting Crime in its Place (pp. 171-198). Springer.

Johnson, S., Bowers, K., \& Pease, K. (2012). Towards the modest predictability of daily burglary counts. Policing, 6(2), 167-176.

Kennedy, L., Caplan, J., \& Piza, E. (2010). Rick clusters, hot spots, and spatial intelligence: Risk terrain modelling as an algorithm for police resource allocation strategies. Journal of Quantitative Criminology, 27, 339-362.
Malleson, N., Evans, A., \& Jenkins, T. (2009). An agent-based model of burglary. Environment and Planning b: Planning and Design, 36, 1103-1123.

Malleson, N., Heppenstall, A., \& See, L. (2010). Crime reduction through simulation: An agent-based model of burglary. Computers, Environment and Urban Systems, 34, 236-250.

McLaughlin, L., Johnson, S., Bowers, K., Birks, D., \& Pease, K. (2007). Police perceptions of the long- and short-term spatial distribution of residential burglary. International Journal of Police Science \& Management, 9(2), 99-111.

Morenoff, J., Sampson, R., \& Raudenbush, S. (2001). Neighbourhood inequality, collective efficacy and the spatial dynamics of urban violence. Criminology, 39(3), 517-559.

Moreto, W., Piza, E., \& Caplan, J. (2014). A plague on both your houses? Risks, repeats and reconsiderations of urban residential burglary. Justice Quarterly, 31(6), 1102-1126.

Office for National Statistics, ONS (2016). Output Areas: Introduction to Output Areas - the building block of Census geography. January 2016. https://www. ons.gov.uk/census/2001censusandearlier/dataandproducts/outputgeog raphy/outputareas. Accessed 24 March 2021.

Office for National Statistics, ONS (2018). User quide to crime statistics for England and Wales. January 2018. Office for National Statistics.

Office for National Statistics, ONS (2019a). Improving victimisation estimates derived from the Crime Survey for England and Wales. Improvements to the way in which victimisation is estimated using the Crime Survey for England and Wales (CSEW) and the impact they have on the survey's outputs. 24 January 2019. Office for National Statistics. https://www.ons.gov.uk/peopl epopulationandcommunity/crimeandjustice/articles/improvingvictim isationestimatesderivedfromthecrimesurveyforenglandandwales/201901-24\#implementation-of-new-methodology-for-measuring-repeat-victi misation-in-published-material. Accessed 24 March 2021

Office for National Statistics, ONS (2019b). Disability and Crime, UK: 2019. Statistical Bulletin. 2 December 2019. Office for National Statistics. https:// www.ons.gov.uk/peoplepopulationandcommunity/healthandsocialcare/ disability/bulletins/disabilityandcrimeuk/2019. Accessed 24 March 2021.

Office for National Statistics, ONS (2020a). Crime in England and Wales: Annual trend and demographic tables year ending March 315t,2020. Office for National Statistics. https://www.ons.gov.uk/peoplepopulationandc ommunity/crimeandjustice/datasets/crimeinenglandandwalesannualtr endanddemographictables. Accessed 24 March 2021.

Office for National Statistics, ONS (2020b). Crime in England and Wales: Police Force Area data tables year ending December 31 $1^{\text {st }}, 2019$. Office for National Statistics. https://www.ons.gov.uk/peoplepopulationandcommunity/ crimeandjustice/datasets/policeforceareadatatables. Accessed 25 June 2020.

Osborn, D. R., \& Tseloni, A. (1998). The distribution of household property crimes. Journal of Quantitative Criminology, 14, 307-330.

Ratcliffe, J. (2004). The hotspot matrix: A framework for the spatial-temporal targeting of crime reduction. Police Practice and Research: an International Journal, 5(1), 5-23.

Sherman, L., Gartin, P., \& Buerger, M. (1989). Hot spots of predatory crime: Routine activities and the criminology of place. Criminology, 27(1), 27-56.

Summers, L., \& Johnson, S. (2017). Does the configuration of the street network influence where outdoor serious violence takes place? Using space syntax to test crime pattern theory. Journal of Quantitative Criminology, 33, 397-420.

Townsley, M., \& Sidebottom, A. (2010). All offenders are equal, but some are more equal than others: Variation in journeys to crime between offenders. Criminology, 48(3), 897-917.

Tseloni, A. (2006). Multilevel modelling of the number of property crimes: Household and area effects. Journal of the Royal Statistical Society A, 169(Part 2), 205-233. https://doi.org/10.1111/j.1467-985X.2005.00388.x

Tseloni, A., Farrell, G., Thompson, R., Evans, E., \& Tilley, N. (2017). Domestic burglary drop and the security hypothesis. Crime Science, 6(3), 2-16.

Tseloni, A., \& Pease, K. (2014). Using modelling to predict and prevent victimization. Springer.

Tseloni, A., Tilley, N., \& Farrell, G. (2018). Victimisation surveys in environmental criminology. In G. Bruinsma \& S. Johnson (Eds.), The Oxford Handbook of Environmental Criminology (pp. 277-296). Oxford University Press.

Tseloni, A., Wittebrood, K., Farell, G., \& Pease, K. (2004). Burglary victimization in England and Wales, the United States, and the Netherlands: A 
cross-national comparative test of routine activities and lifestyle theories. British Journal of Criminology, 44(1), 66-91.

Vandeviver, C., \& Steenbeek, W. (2019). The (in)stability of residential burglary patterns on street segments: The case of Antwerp, Belgium 2005-2016. Journal of Quantitative Criminology, 35, 111-113.

Vandeviver, C., Van Daele, S., \& Vander Beken, T. (2015). What makes long trips worth undertaking? Balancing costs and benefits in burglars'journey to crime. British Journal of Criminology, 55(2), 399-420.

Weisburd, D. (2015). The law of crime concentration and the criminology of place. Criminology, 53(2), 133-157.
Weisburd, D., Telep, C., \& Lawton, B. (2014). Could innovations in policing have contributed to the New York City crime drop even in a period of declining police strength? The case of stop, question and frisk as a hot spots policing strategy. Justice Quarterly, 31(1), 129-153.

\section{Publisher's Note}

Springer Nature remains neutral with regard to jurisdictional claims in published maps and institutional affiliations.
Ready to submit your research? Choose BMC and benefit from:

- fast, convenient online submission

- thorough peer review by experienced researchers in your field

- rapid publication on acceptance

- support for research data, including large and complex data types

- gold Open Access which fosters wider collaboration and increased citations

- maximum visibility for your research: over $100 \mathrm{M}$ website views per year

At BMC, research is always in progress.

Learn more biomedcentral.com/submissions 